See discussions, stats, and author profiles for this publication at: https://www.researchgate.net/publication/343481376

\title{
Quantifying deformation processes in the SE Pyrenees using U-Pb dating of fracture-filling calcites
}

Article in Journal of the Geological Society · August 2020

DOI: 10.1144/jgs2020-014

CITATIONS

0

7 authors, including:

David Cruset

Geosciences Barcelona (Geo3Bcn) CSIC

23 PUBLICATIONS 49 CITATIONS

SEE PROFILE

R. Albert

Goethe-Universität Frankfurt am Main Universität zu Köln

40 PUBLICATIONS 419 CITATIONS

SEE PROFILE
255



Some of the authors of this publication are also working on these related projects:

Continent collision in Atlantic Canada View project

Fluid flow during the evolution of an orogen: diagenetic, hydrothermal and metamorphic characterization applied to gas storage and mineral exploration View project 


\title{
Quantifying deformation processes in the SE Pyrenees
}

\section{using $\mathrm{U}-\mathrm{Pb}$ dating of fracture-filling calcites}

\author{
D. Cruset ${ }^{1,2}$, J. Vergés ${ }^{2}$, R. Albert ${ }^{3,4}$, A. Gerdes ${ }^{3,4}$, A. Benedicto ${ }^{5}$, I. Cantarero ${ }^{1}$, A. \\ Travé $^{1}$
}

${ }^{1}$ Departament de Mineralogia, Petrologia i Geologia Aplicada, Facultat de Ciències de la Terra, Universitat de Barcelona (UB), Martí i Franquès s/n, 08028, Barcelona, Spain.

i cantarero@ub.edu,atrave@ub.edu

2 Group of Dynamics of the Lithosphere (GDL), Institut de Ciències de la Terra Jaume Almera, ICTJA-CSIC, Lluís Solé i Sabaris s/n, 08028 Barcelona, Spain.

dcruset@ictja.csic.es, jverges@ictja.csic.es

3 Department of Geosciences, Goethe University Frankfurt, 60438 Frankfurt am Main, Germany. gerdes@em.uni-frankfurt.de, albertroper@em.uni-frankfurt.de

${ }_{4}$ Frankfurt Isotope and Element Research Center (FIERCE), Goethe University Frankfurt, Frankfurt am Main, Germany.

${ }^{5}$ UMR Geops, Université Paris Sud, 91405 Orsay, France. antonio.benedicto@u-psud.fr

\section{ABSTRACT}

A significant challenge in brittle fold and thrust belts analysis is to quantify the timing of the deformation processes, since suitable minerals for dating and well-preserved growth strata sediments are scarce or absent. Here, we quantify the duration of thrust sheet emplacement and shortening rates in the SE Pyrenean thrust sequence using U-Pb dating of fracture-filling calcites. The obtained $\mathrm{U}-\mathrm{Pb}$ dates reveal a minimum duration for the emplacement of each thrust unit (18.7 Ma for the Bóixols-Upper Pedraforca, 11.6 Ma for the Lower Pedraforca and 14.3 Ma for the Cadí), and that piggy-back thrusting was accompanied by post-emplacement deformation of upper thrust sheets above lower ones during their south-directed tectonic transport. Shortening rates of 0.6 $\mathrm{mm} / \mathrm{yr}, 3.1 \mathrm{~mm} / \mathrm{yr}$ and $1.1 \mathrm{~mm} / \mathrm{yr}$ from older to younger emplaced thrust sheets were calculated. The results also reveal the formation of local normal faults during the late 
31 Oligocene as a result of the late stages of compression and exhumation in the SE

32 Pyrenees. Finally, we observed that temperatures higher than $110^{\circ} \mathrm{C}$ could be a limiting factor when applying the U-Pb dating method.

Keywords: U-Pb calcite geochronology, deformation, SE Pyrenean fold and thrust belt.

\section{INTRODUCTION}

In the upper crust, compressional deformation leads to the development of brittle fracturing. Fracture sets show complex crosscutting relationships and document polyphase deformation and long-lasting thrusting (and folding) accompanied with fluid flow and precipitation of fracture-filling cement (e.g., Zhang et al., 2004; Roure et al. 2005; Travé et al., 2007; Cosgrove, 2015). One of the most common fracture-filling minerals is calcite, which very often shows syn-kinematic textures and therefore, a direct relationship with tectonic deformation (e.g., Travé et al., 1998; Bons et al., 2012).

In large orogenic belts, the timing and duration of ductile thrusting has been constrained using U-Pb dating of metamorphic minerals (e.g., Mottram et al., 2015). This approach has been a challenge to apply to brittle fold and thrust belts due to the lack of suitable minerals for dating or well-preserved growth strata sediments. However, recently, U-Pb dating of calcite has been used to constrain the absolute timing of brittle deformation in compressional settings (Beaudoin et al., 2018; Hansman et al., 2018; Parrish et al., 2018). The development of this dating method has opened the possibility to quantify thrusting duration and shortening rates in the brittle realm.

The southern Pyrenees is a fold and thrust belt in which the sequence of thrusting is well-known due to the exceptional preservation of the thrust sheets and growth strata sediments deposited in the thrust front (e.g., Meigs et al., 1996; Vergés et al., 2002; 
the south Pyrenean thrust sheets has allowed for several fluid flow studies in this fold and thrust belt in the last decades (Travé et al., 1997, 2007; Beaudoin et al., 2015; Cruset et al., 2016, 2018; Crognier et al., 2018; Cruset, 2019; Nardini et al., 2019). This abundance of fracture-filling calcites throughout the entire pile of thrust sheets reveals the southern Pyrenees as the perfect site for proving the quantification of deformation processes using $\mathrm{U}-\mathrm{Pb}$ calcite dating during the complete evolution of a fold and thrust belt.

In this study we present a new data set of $46 \mathrm{U}-\mathrm{Pb}$ ages obtained from 66 fracture-filling calcites sampled in the piggy-back thrust sequence of SE Pyrenean fold and thrust belt. The results enable us to provide more precise information regarding deformation processes in the SE Pyrenees, such as the minimum duration of thrust sheet emplacement and shortening rates. Furthermore, the obtained U-Pb dates allow us to constrain in time the changes of the main stress orientations and the shift from compressional to extensional deformation, as well as to prove the coexistence between both tectonic regimes. Finally, we comment on the possible influence of temperature on the suitability of calcite for U-Pb geochronology. To do this, we have considered previously published clumped isotopes data from Cruset et al. (2016; 2018; 2019; 2020), Cruset (2019) and in Nardini et al. (2019) of several of the dated fracture-filling calcites used in this study.

\section{GEOLOGICAL SETTING}

The Pyrenees formed within the framework of the Alpine orogeny and consist of a doubly verging orogenic belt generated during the continental collision between Iberia and Eurasia plates (Fig. 1A), from Late Cretaceous to Miocene (Muñoz, 2002; Vergés et al., 2002). This collision resulted from the partial subduction of the Iberian plate 
beneath the Eurasian plate (e.g., Choukroune, et al., 1989; Roure et al., 1989; Muñoz, 1992; Vergés et al., 2002; Chevrot et al., 2018; Grool et al., 2018; Teixell et al., 2018).

The SE Pyrenees consist of a south-directed piggy-back thrust sequence emplaced from Late Cretaceous to Oligocene. This sequence consists of the stacking of three thrust sheets and a deformed foreland basin (Fig. 1B and C). From top-and-older to bottomand-younger, these are the Bóixols-Upper Pedraforca, the Lower Pedraforca and the Cadí thrust sheets, and the Ebro foreland basin (Vergés et al., 2002).

The Bóixols-Upper Pedraforca thrust sheet consists of an extensional basin affected by diapirism and incorporated into the Pyrenean orogen during the Late CretaceousPalaeocene compression (Puigdefàbregas and Souquet, 1986; Saura et al., 2015). The Upper Pedraforca thrust sheet emplaces an up to $1.6 \mathrm{~km}$ thick succession of Upper Triassic, Jurassic and Cretaceous pre-compressive sedimentary rocks over Upper Cretaceous to Palaeocene syn-orogenic sediments of the south Pyrenean foreland basin (Vergés et al., 2002).

The Lower Pedraforca thrust sheet consists of an allochthonous klippe detached in the Upper Triassic Keuper facies and emplaced from Lower to Middle Eocene (Puigdefàbregas et al., 1986; Burbank et al., 1992). This thrust unit places Upper Triassic and Jurassic pre-compressive sedimentary successions and upper Cretaceous to Paleocene syn-orogenic deposits over Eocene foredeep marine sediments of the Cadí thrust sheet. The rocks forming the Lower Pedraforca thrust sheet have a thickness of up to $2400 \mathrm{~m}$ in its northern imbricate and less than $500 \mathrm{~m}$ in the southernmost thrust nappes. The emplacement of this thrust unit was under marine conditions, as attested by the syn-orogenic fan delta conglomerates deposited at the thrust front (Vergés, 1993). 
102 The lowermost Cadí thrust sheet is linked to the Axial Zone antiformal stack formed by 103 the Orri and Rialp basement thrusted units (Muñoz, 1992) (Fig. 1C), which are 104 unconformably overlain by thin Mesozoic rocks and thick Paleogene rocks. This thrust 105 sheet has a thickness of up to $3 \mathrm{~km}$ in its northern sector and up to $1 \mathrm{~km}$ in the south. 106 The southern boundary of the Cadí thrust sheet is the Vallfogona thrust, which places 107 middle Eocene syn-orogenic marine deposits over Eocene-Oligocene continental deposits of the Foreland Ebro basin (Burbank et al., 1992; Vergés et al., 2002). The activity of this thrust fault started in the middle Eocene under marine conditions and finished during the lower Oligocene under continental conditions (Burbank et al., 1992).

The Ebro foreland basin represents the non-marine stage of the South Pyrenean foreland basin (Vergés et al, 2002), which developed from the middle Priabonian (Costa et al., 2010). The fold system deforming the eastern region of the Ebro foreland basin was detached above the Cardona evaporites (Sans et al., 1996).

\section{METHODOLOGY}

Field work consisted of structural data acquisition and sampling of veins in damage zones of main reverse, strike-slip and normal faults in both pre-shortening rocks as well as in syn-orogenic deposits (Figs. 1 and $\mathrm{S} 1$ and Table S1). Previous fracture data from Cruset et al. (2016; 2018; 2019; 2020), Cruset (2019) and Nardini et al. (2019) have been integrated in this study. In these previous works, fracture types were divided considering crosscutting relationships, the direction and sense of motion on individual fault planes determined by striae sets, and orientations of stress axes deduced from conjugate sets of veins. 
124 Fracture-filling cement was characterized by means of optical and cathodoluminescence microscope to determine their mineralogy and texture. From 66 samples, 35 mounts were prepared for $\mathrm{U}-\mathrm{Pb}$ dating.

The U-Pb dating method is similar to that previously described by Ring and Gerdes (2016) and Burisch et al. (2017). U-Pb dates were acquired using laser ablationinductively coupled plasma mass spectrometry (LA-ICPMS) at FIERCE (Frankfurt Isotope and Element Research Center, Goethe Universität), applying a modified method of Gerdes and Zeh (2006, 2009). A ThermoScientific Element XR sector field ICPMS was coupled to a RESOlution 193nm ArF excimer laser (COMpexPro 102) equipped with a two-volume ablation cell (Laurin Technic S155). Samples were ablated in a helium atmosphere $(300 \mathrm{~mL} / \mathrm{min})$ and mixed in the ablation funnel with $1100 \mathrm{~mL} / \mathrm{min}$ argon and $5 \mathrm{~mL} / \mathrm{min}$ nitrogen. Signal strength at the ICP-MS was tuned for maximum sensitivity whereas keeping the oxide formation (monitored as ${ }^{248} \mathrm{ThO} /{ }^{232} \mathrm{Th}$ ) below $0.2 \%$ and no fractionation of the $\mathrm{Th} / \mathrm{U}$ ratio. Static ablation used a spot size of $213 \mu \mathrm{m}$ and a fluency of about $2 \mathrm{~J} / \mathrm{cm}$ at $12 \mathrm{~Hz}$. For NIST SRM-614 this yielded a depth penetration of $\sim 0.6 \mu \mathrm{m} / \mathrm{s}$ and an average sensitivity of $380,000 \mathrm{cps} / \mu \mathrm{g}$ for ${ }^{238} \mathrm{U}$. The detection limit for ${ }^{206} \mathrm{~Pb}$ and ${ }^{238} \mathrm{U}$ was $\sim 0.2$ and $0.03 \mathrm{ppb}$, respectively.

Data were acquired in fully automated mode overnight in three sequences of 598 analyses each. Each analysis consisted of $18 \mathrm{~s}$ of background acquisition followed by 18 s of sample ablation and $25 \mathrm{~s}$ of washout. During $36 \mathrm{~s}$ of data acquisition, the signal of ${ }^{206} \mathrm{~Pb},{ }^{207} \mathrm{~Pb},{ }^{208} \mathrm{~Pb},{ }^{232} \mathrm{Th}$, and ${ }^{238} \mathrm{U}$ was detected by peak jumping in pulse-counting and analogue mode with a total integration time of $\sim 0.1 \mathrm{~s}$, resulting in 370 mass scans. Before analysis, each spot was pre-ablated with 8 laser pulses to remove surface contamination. Soda-lime glass NIST SRM-614 was used as primary reference material 
(RM) together with three carbonate RMs, which were bracketed in between the analysis of samples (see Table S2 for validation results).

Raw data were corrected offline using an in-house VBA spreadsheet program (Gerdes and Zeh, 2006, 2009). Following background correction, outliers $( \pm 2 \sigma)$ were rejected based on the time-resolved ${ }^{207} \mathrm{~Pb} /{ }^{206} \mathrm{~Pb},{ }^{208} \mathrm{~Pb} /{ }^{206} \mathrm{~Pb},{ }^{206} \mathrm{~Pb} /{ }^{238} \mathrm{U}$, and ${ }^{232} \mathrm{Th} /{ }^{238} \mathrm{U}$ ratios. These ratios were corrected for mass biases and drift over time, using NIST SRM-614. Due to the carbonate matrix, an additional correction was applied (sequence 1: $4.8 \%$, sequence 2: $10.6 \%$, sequence 3: $11.8 \%$ ), which was determined using WC-1 carbonate RM (Roberts et al., 2017). The ${ }^{206} \mathrm{~Pb} /{ }^{238} \mathrm{U}$ downhole-fractionation during 20 s depth profiling was estimated to be $3 \%$, based on the common $\mathrm{Pb}$ corrected $\mathrm{WC}-1$ analyses, and was applied as an external correction to all carbonate analyses. Uncertainties for each isotopic ratio are the quadratic addition of the within run precision, counting statistic uncertainties of each isotope, and the excess of variance (Horstwood et al., 2016) calculated from the SRM-614 and the WC-1 after drift correction. In case of the $208 \mathrm{Pbcom} / 206 \mathrm{~Pb}$ ratio the uncertainty from the radiogenic $208 \mathrm{~Pb}$ correction was also added. To account for the long-term reproducibility of the method we added by quadratic addition an expanded uncertainty of $1.5 \%$ to the final age of all analysed carbonates. This was deducted from repeated analyses $(n=7)$ of ASH-15D between 2017 and 2019. A summary report of the U-Pb dating procedure is presented in Table S2.

Reference material ASH-15D (2.936 \pm 0.140 and 2.908 $\pm 0.122 \mathrm{Ma}$; Vaks et al., 2013) was measured in sequences 2 and 3 for quality control. In addition, a stromatolitic limestone from the Cambrian-Precambrian boundary in South-Namibia (here called NAMA) was analysed during sequences 1 and 3, as an in-house RM for quality control 
172 (obtained ages agree with the $\mathrm{U} / \mathrm{Pb}$ zircon age of $540.1 \pm 0.1 \mathrm{Ma}$ from the directly 173 overlying ash layer, Spitskopf formation; Linnemann et al. 2018). Results on the secondary RM imply an accuracy and repeatability of the method of about 1.5 to $2 \%$.

The analytical results are presented in Tables S2 and S3. Data were displayed in TeraWasserburg plots (Table S2) and ages were calculated as lower concordia-curve 177 intercepts using the same algorithms as Isoplot 4.14 (Ludwig, 2012). In addition, the 178 data was plotted in the modified ${ }^{208} \mathrm{~Pb} /{ }^{206} \mathrm{~Pb}$ vs. ${ }^{238} \mathrm{U} /{ }^{206} \mathrm{~Pb}$ Tera-Wasserburg diagrams after correction for radiogenic ${ }^{208} \mathrm{~Pb}$ and ages were calculated from the $\mathrm{X}$-axis intercepts (Parrish et al. 2018). In all cases, the ages overlapped within their uncertainties and thus showed a 1 to 1 correlation between the ${ }^{208} \mathrm{~Pb} /{ }^{206} \mathrm{~Pb}$ - and ${ }^{207} \mathrm{~Pb} /{ }^{206} \mathrm{~Pb}$-based TeraWasserburg age. The ages discussed in this paper are the Tera-Wasserburg intercept ages. All uncertainties are reported at the $2 \sigma$ level.

\section{RESULTS}

\subsection{Fracture analysis}

The studied samples consisted of calcite cement precipitated in four fracture sets related to compressional tectonics and in one extensional set, all of them already described in Cruset et al., (2016; 2018; 2019; 2020), Cruset (2019) and Nardini et al. (2019) (Figs. 2, 3 and S1). The compressional sets include: 1) N-S, NNW-SSE and NNE-SSW trending en-échelon vein arrays (Fig. 2A); 2) E-W trending folding-related veins (Fig. 2B); 3) EW trending reverse faults Fig. 2C); and 4) NW-SE and NE-SW trending strike-slip faults (Fig. 2D). The extensional fracture set corresponds to NNW-SSE and NW-SE trending normal faults (Fig. 2E). 
folding-related veins are bed-perpendicular, and cut the hangingwall of thrust sheets, whereas reverse and strike-slip faults are mainly located along the basal thrust zones (Fig 3A). Normal faults are observed in the crest of the Puig-reig anticline, in the Ebro basin, and cutting the northern domain of the SE Pyrenean thrust system (Fig. 3A). The stereographic projection of measured fracture sets and the calculated orientation of main stresses indicate a N-S compression for compressional fracture sets and an NE-SW extension for the extensional set (Figs. 3B and S1).

\subsection{Calcite cement petrography}

205

The five different fracture sets contain bladed, blocky, and elongated calcite cement. Karstic breccias in Jurassic rocks of the Bóixols-Upper Pedraforca thrust sheet and a fault breccia in Eocene-Oligocene rocks from the Ebro foreland basin also have been studied for U-Pb calcite dating. These breccias only contain blocky and bladed calcite crystals.

Bladed crystals are up to $2 \mathrm{~mm}$ long (Fig. 4A and B) and have been observed mainly in N-S, NNW-SSE and NNE-SSW veins. The disposition of these crystals indicates that their growth occurred from both fracture walls to the vein centre or from one vein wall to another. Blocky crystals have a size ranging between $100 \mu \mathrm{m}$ and $3 \mathrm{~mm}$ (Fig. 4C and D). They have been observed in N-S, NNW-SSE and NNE-SSW and E-W foldingrelated veins, as well as in rhomb-shaped veinlets formed by crack-seal mechanism in reverse and strike-slip faults (Fig. 4E and F). In these faults, blocky calcites are also arranged in stepped slickensides, thus indicating the sense of shear. In N-S, NNW-SSE and NNE-SSW veins, blocky crystals occasionally contain trails of host-rock arranged 
parallel to fracture walls and perpendicular to the opening direction, also indicating a crack-seal mechanism of vein formation (Fig. 4G).

Elongated calcite crystals are arranged parallel, oblique, or perpendicular to fracture walls and have lengths ranging between $400 \mu \mathrm{m}$ and $3 \mathrm{~mm}$ (Fig 5A to F). Elongated calcite crystals arranged perpendicular to fracture walls are observed in N-S, NNW-SSE and NNE-SSW trending veins. Elongated crystals arranged parallel or oblique to fracture walls are observed in reverse faults, strike-slip faults and in normal faults. The disposition of the oblique elongated crystals with respect to fracture planes and stepped slickensides containing elongated calcite parallel to fracture walls indicate the sense of shear (Fig. 5E and F).

\section{3. $U$-Pb calcite dating}

Using U-Pb geochronology, we document 46 dates, ranging from $70.6 \pm 0.9$ Ma to $2.8 \pm$ 1.8 Ma, obtained from 43 fracture-filling calcites and three calcites precipitated between karstic and fault breccia clasts (Figs. 6 and Tables S2 and S3). In the Bóixols-Upper Pedraforca thrust sheet, dates range from $70.6 \pm 0.9$ Ma to $12.7 \pm 2.9$ Ma (Fig. 6). For the Lower Pedraforca thrust sheet, dates range from $48.3 \pm 1.3 \mathrm{Ma}$ to $13.4 \pm 1.5 \mathrm{Ma}$ and for the Cadí unit from $36.7 \pm 1.5 \mathrm{Ma}$ to $4.6 \pm 4.6 \mathrm{Ma}$ (Fig. 6). This last young date (sample C12), as well as the one obtained in cement within fault breccia clasts from the Ebro foreland basin (sample GPR401; $2.8 \pm 1.8 \mathrm{Ma}$; Fig. 6), have high uncertainties and high proportions of common lead, resulting in sub-horizontal arrays (Table. S2) and in consequence, they are not considered in the discussion. Two U-Pb dates measured in calcite cement within karstic breccias in Jurassic rocks of the Bóixols-Upper Pedraforca thrust sheet yield ages between $37.1 \pm 0.7 \mathrm{Ma}$ and $34.4 \pm 0.9 \mathrm{Ma}$ (samples P9a and $\mathrm{P9b})$. 


\section{DISCUSSION}

244 Textures of dated fracture-filling calcites provide information regarding precipitation processes and their relationship with fracturing. In this sense, calcites exhibiting elongated blocky textures provide evidence for syn-kinematic growth (Fig 5; Table S1).

On the other hand, blocky and bladed textures indicate precipitation after vein opening or at lower rates than vein opening. Despite this, the presence of some of the studied blocky textures in veins formed by crack-seal mechanism and in stepped slickensides also indicates syn-kinematic growth. Furthermore, clumped isotopes thermometry applied to several of these blocky and bladed calcites, presented previously in Cruset et al. $(2016 ; 2018 ; 2019 ; 2020)$ and Cruset $(2019)$, indicate that most of them precipitated from fluids in thermal disequilibrium with their adjacent host rocks. This disequilibrium indicates rapid fluid flow and precipitation just after fracture opening (Bons et al., 2012; Beaudoin et al., 2014), thus suggesting that the studied blocky and bladed calcites dated in this study are also syn-kinematic.

The results obtained in this study evidence certain limitations of the U-Pb method in the southern Pyrenees. Firstly, the U-Pb dating failed in calcite cement $\mathrm{Cc} 2$ from the Vallfogona thrust and northern Cadí thrust sheet (with clumped temperatures of $154 \pm 2$ ${ }^{\circ} \mathrm{C}$ and $113 \pm 9{ }^{\circ} \mathrm{C}$, respectively), calcite cement $\mathrm{Cc} 1$ in the Puig-reig anticline (129 \pm 8 $\left.{ }^{\circ} \mathrm{C}\right)$, and in dolomite cement Dc1 $\left(149.4 \pm 12.5^{\circ} \mathrm{C}\right)$ and $\mathrm{Dc} 2\left(124.7 \pm 6.2^{\circ} \mathrm{C}\right)$ in the Upper Pedraforca thrust sheet (temperatures are from Cruset et al., 2016; 2018; 2019; 2020 and Cruset, 2019; Table 1). All these samples have temperatures above $110^{\circ} \mathrm{C}$ and too high initial $\mathrm{Pb} / \mathrm{U}$ contents, suggesting that temperature could be a limiting parameter of the U-Pb dating method. Secondly, U-Pb dating also failed in fracture-filling calcites hosted in siliciclastic deposits, which derived from igneous and metamorphic basement sources (e.g., GDV13, 309B; 311A; Table S1). In these samples, the lead content is 
high (from 2.9 to $29.0 \mathrm{ppm}$ and a mean value of $13.8 \mathrm{ppm}$; Table S2), whereas the $\mathrm{U}$ content is within the magnitude of some successful samples (between 2 and $659 \mathrm{ppb}$ and a mean value of $85 \mathrm{ppb}$; Table S2). Such high lead content indicates the influence of the host rock composition on successful U-Pb dating.

272 Despite these limitations, the obtained U-Pb dataset fits with the timing of deformation 273 within the SE Pyrenean piggy-back thrust system, already constrained by a large number of growth strata units dated by both biostratigraphic analysis for marine deposits, and magnetostratigraphy and apatite fission-track thermochronology for nonmarine deposits (e.g., Meigs et al., 1996; Beamud et al., 2010; Rahl et al., 2011; Rushlow et al., 2013; Carrigan et al., 2016; Fig. 6). Furthermore, the results provide broader information regarding the duration of thrusting propagation and pervasive deformation of the upper SE Pyrenean thrust sheets. Dates obtained in the BóixolsUpper Pedraforca thrust sheet ranging from $70.6 \pm 0.9 \mathrm{Ma}$ to $55.3 \pm 0.5 \mathrm{Ma}$ are older than Palaeocene syn-tectonic sediments fossilizing this structure (Tavani et al., 2017). Therefore, they have been interpreted to be related to the emplacement of this thrust unit and record a minimum period of $15.3 \mathrm{Ma}$ (Fig. 6). Thus, younger U-Pb dates obtained in the Bóixols-Upper Pedraforca from $48.9 \pm 3.1$ to $25.7 \pm 1.9$ Ma are thus related to its post-emplacement (Figs. 6 and 7). In this line, dates ranging from $48.9 \pm 3.1$ Ma to 44.7 \pm 4.1 Ma are coeval with the emplacement of the Lower Pedraforca thrust sheet (Vergés et al., 2002; Grool et al., 2018). U-Pb dates obtained in this thrust unit from fracturefilling calcites in both pre-compression rocks and Lutetian growth strata lying along the thrust front range from $48.3 \pm 1.3 \mathrm{Ma}$ to $41.5 \pm 0.7 \mathrm{Ma}$. The two U-Pb dates of $\sim 41 \mathrm{Ma}$ fit with the initial emplacement of the Cadí thrust sheet but also with the development of the Lower Pedraforca imbricates (Burbank et al., 1992). Thus, the U-Pb dates measured in this thrust unit document a minimum duration of emplacement of $7.3 \mathrm{Ma}$ 
and suggest that it was $~ 5.4$ Ma younger than previous estimates (Vergés et al. 2002; Fig. 6). The uppermost Bóixols-Upper Pedraforca also registers dates ranging from 39.5 $\pm 1.2 \mathrm{Ma}$ to $25 \pm 17 \mathrm{Ma}$, which are consistent with the U-Pb dates measured in the Cadí unit ranging from $38.8 \pm 1.1$ to $25.7 \pm 1.9 \mathrm{Ma}$ (Fig. 6). Considering these BartonianChattian $\mathrm{U}-\mathrm{Pb}$ dates in both thrust units, we estimate a minimum duration of emplacement of 12.9 Ma for the Cadí thrust sheet. Post-Oligocene dates have not been used in these calculations since compressional deformation in the SE Pyrenees finished in the Oligocene (Vergés et al., 2002; Grool et al., 2018). The estimated durations for the emplacement of the SE Pyrenean thrust sheets are calculated from U-Pb dates without considering time gaps between each unit (Fig. 6, dotted grey lines). In a scenario of continuous thrust sheet propagation as suggested by Vergés et al. (2002) and Grool et al. (2018), and considering the time gaps, maximum emplacement durations of 18.8 Ma, 11.6 Ma and 14.3 Ma are obtained for the Bóixols-Upper Pedraforca, Lower Pedraforca and Cadí thrust sheets, respectively.

The spatial distribution of the U-Pb dates reflects the thrust propagation history of the SE Pyrenees. In this sense, dates from the Bóixols-Upper Pedraforca register its emplacement from Late Cretaceous to Palaeocene and its post-emplacement deformation above the Lower Pedraforca and Cadí from early Eocene to late Oligocene (Fig. 7). Such post-emplacement deformation is also observed in the Lower Pedraforca, where the early Oligocene date of $30 \pm 1.4$ Ma records its deformation above the Cadí unit. In the same line, late Oligocene U-Pb dates of $29.3 \pm 1.8 \mathrm{Ma}$ and $25.9 \pm 8.9 \mathrm{Ma}$ obtained in the Cadí unit are coeval with dated growth strata within foreland (Meigs et al., 1996; Carrigan et al., 2016; Figs. 6 and 7). 
316 Another important information provided by the U-Pb results is related to the rates of 317 thrust sheet emplacement and their variations through time in fold and thrust belts. To 318 calculate these rates, we used the minimum shortening already established by Vergés et al. (2002) and Grool et al. (2018) for the Bóixols-Upper Pedraforca (11 km), Lower Pedraforca $(36.2 \mathrm{~km})$ and Cadí $(16.4 \mathrm{~km})$ thrust sheets and the durations of emplacement estimated from $\mathrm{U}-\mathrm{Pb}$ dating measured in the studied fracture-filling calcites. Shortening values were obtained from the restoration of both cover and basement thrust sheets represented in the balanced cross-section J3 from Vergés (1993), which is the most representative of the studied area. Thus, maximum rates of $0.7 \mathrm{~mm} / \mathrm{yr}$ for the Bóixols-Upper Pedraforca (11 km/15.3 Ma), $4.9 \mathrm{~mm} / \mathrm{yr}$ for the Lower Pedraforca $(36.2 \mathrm{~km} / 7.3 \mathrm{Ma})$ and $1.3 \mathrm{~mm} / \mathrm{yr}$ for the Cadí $(16.4 \mathrm{~km} / 12.9 \mathrm{Ma})$ thrust sheets are obtained. On the other hand, considering the time gaps between each thrust sheet, rates of $0.6 \mathrm{~mm} / \mathrm{yr}, 3.1 \mathrm{~mm} / \mathrm{yr}$ and $1.1 \mathrm{~mm} / \mathrm{yr}$ are calculated (Fig. 6). In this last scenario, the calculated rates are within the same range of previous estimates calculated for the southern Pyrenees from balanced and restored cross-sections combined with stratigraphic constraints (between 0.4 and less than $4 \mathrm{~mm} / \mathrm{yr}$; Grool et al., 2018).

Finally, from $70.6 \pm 0.9$ Ma to $25.9 \pm 8.9 \mathrm{Ma}$, the dominant stress regime shows a N-S compression that agrees with the mean Pyrenean tectonic transport direction (compressional fracture sets; Fig. 7), whereas local normal faults showing NE-SW extension formed from $30 \pm 1.4$ Ma to $12.7 \pm 2.9 \mathrm{Ma}$ (extensional fracture set; Fig. 7). The orientations of these analysed normal faults do not fit with the main E-W trend observed in the SE Pyrenean folds and thrusts, except for those formed by crestal collapse in the Puig-reig anticline (Fig. S1). Therefore, Oligocene normal faults could have formed during the exhumation of the central and south eastern Pyrenees related to the compression and stacking of its hinterland according to thermochronological data 
341 (e.g., Fitzgerald et al., 1999, Gibson et al., 2007; Fillon and van der Beek, 2012;

342 Rushlow et al., 2013). The areal restriction of NNW-SSE normal faults at the northern

343 domain of the Bóixols-Upper Pedraforca, Lower Pedraforca and Cadí thrust sheets and

344 their coexistence with compressional veins showing $\mathrm{U}-\mathrm{Pb}$ ages of $28.4 \pm 0.8 \mathrm{Ma}, 25.9 \pm$

$3458.9 \mathrm{Ma}$ and $25.7 \pm 1.9 \mathrm{Ma}$ supports this exhumation scenario (samples B32, B46 and

346 P12a, respectively; Figs. 6 and 7). Contrarily, Miocene normal faults and reactivated

347 reverse faults probably formed during the post-orogenic exhumation and collapse of the

348 SE Pyrenees during upstream incision of the Ebro basin before its capture by the

349 Mediterranean Sea at 12 to $8.5 \mathrm{Ma}$ (Garcia-Castellanos et al., 2003; Fillon and van der

350 Beek, 2012; Rushlow et al., 2013; Pérez-Rivarés et al., 2018). According to these

351 authors, the Ebro basin capture resulted in the lowering of the regional base level and

352 the excavation of the buried SE Pyrenean fold and thrust belt.

\section{CONCLUSIONS}

Duration of thrust sheet emplacement and shortening rates in the SE Pyrenean piggyback thrust system were quantified applying $\mathrm{U}-\mathrm{Pb}$ geochronology to fracture-filling calcites. The results reveal emplacement durations of 18.8 Ma for the Bóixols-Upper Pedraforca, 11.6 Ma for the Lower Pedraforca and 14.3 Ma for the Cadí unit, with shortening rates of $0.6,3.1$ and $1.1 \mathrm{~mm} / \mathrm{yr}$, respectively. U-Pb dates also indicate that during progressive south-directed Pyrenean thrust sheet stacking, emplacement of lower thrust sheets deformed the previously emplaced upper ones. Furthermore, local normal faults with Late Oligocene ages from $30 \pm 1.4$ to $25.7 \pm 1.9 \mathrm{Ma}$ are consequence of the Pyrenean hinterland exhumation during the late compressional stages. Finally, U-Pb dates indicate that in the SE Pyrenees, temperatures higher than $110{ }^{\circ} \mathrm{C}$ influence negatively in the suitability of calcite and dolomite for dating. 
366 This research was carried out within the framework of DGICYT Spanish Project PGC2018-093903-B-C22 Ministerio de Ciencia, Innovación y Universidades/Agencia

Estatal de Investigación/Fondo Europeo de Desarrollo Regional, Unión Europea, and

Grups Consolidats de Recerca "Geologia Sedimentària" (2017SGR-824) and

"Modelització Geodinàmica de la Litosfera" (2017SGR-847). This is FIERCE

contribution No. XX. We thank Nick Roberts, Guilhem Hoareau and the Editor Randall

Parrish for their constructive comments that improved the quality of the manuscript.

Also, we would like to thank Katherine Mottram, Elena Druget and Chris Clark for geological discussions of a previous version of the manuscript. Finally, we thank Frances Luttikhuizen for the linguistic revision of this draft of the manuscript.

\section{REFERENCES}

Beamud, E., Muñoz, J.A., Fitzgerald, P.G., Baldwin, S.L., Garcés, M., Cabrera, L., Metcalf, J.R., 2010. Magnetostratigraphy and detrital apatite fission track thermochronology in syntectonic conglomerates: constraints on the exhumation of the South-Central Pyrenees. Basin Research 23, 309-331.

Beaudoin, N., Bellahsen, N., Lacombe, O., Emmanuel, L., Pironon, J., 2014. Crustalscale fluid flow during the tectonic evolution of the Bighorn Basin (Wyoming, USA). Basin Research 26, 403-435.

Beaudoin, N., Huyghe, D., Bellahsen, N., Lacombe, O., Emmanuel, L., Mouthereau, F., Ouanhnon, L., 2015. Fluid systems and fracture development during syndepositional fold growth: An example from the Pico del Aguila anticline, Sierras Exteriores, southern Pyrenees, Spain. Journal of Structural Geology 70, 23-38. 
Beaudoin, N., Lacombe, O., Roberts, N.M.W., Koehn, D., 2018. U-Pb dating of calcite veins reveals complex stress evolution and thrust sequence in the Bighorn Basin, Wyoming, USA. Geology 46, 1015-1018.

Bons, P.D., Elburg, M.A., Gómez-Rivas, E., 2012. A review of the formation of tectonic veins and their microstructures. Journal of Structural Geology 43, 3362.

Burbank, D.W., Puigdefàbregas, C. \& Muñoz, J.A. 1992. The chronology of the Eocene tectonic and stratigraphic development of the Eastern Pyrenean Foreland Basin. NE Spain. Geol. Soc. America Bull., 104, 1101-1120.Burisch, M., Gerdes, A., Walter, B.F., Neumann, U., Fettel, M., Markl, G., 2017. Methane and the origin of five-element veins: Mineralogy, age, fluid inclusion chemistry and ore forming processes in the Odenwald, SW Germany. Ore Geology Reviews 81, $42-61$.

Carrigan, J.H., Anastasio, D.J., Kodama, K.P., Parés, J.M., 2016. Fault-related fold kinematics recorded by terrestrial growth strata, Sant Llorenç de Morunys, Pyrenees Mountains, NE Spain. Journal of Structural Geology 91, 161-176.

Chevrot, S., Sylvander, M., Diaz, J., Martin, R., Mouthereau, F., Manatschal, G., Masini, E., Calassou, S., Grimaud, F., Pauchet, H., Ruiz, M., 2018. The noncylindrical crustal architecture of the Pyrenees. Scientific Reports 8, 9591.

Choukroune, P., Roure, F., Pinet, B., TEAM, E.P., 1990. Main results of the ECORS Pyrenees profile. Tectonophysics 173, 411-423.

Cosgrove, J.W., 2015. The association of folds and fractures and the link between folding, fracturing and fluid flow during the evolution of a fold-thrust belt: a brief review. Geological Society, London, Special Publications 421, SP421.411. 
412 Costa, E., Garcés, M., López-Blanco, M., Beamud, E., Gómez-Paccard, M. \& Larrasoaña, J.C. 2010. Closing and continentalization of the South Pyrenean foreland basin (NE Spain): magnetochronological constraints. Basin Research, 22, 904-917.

Crognier, N., Hoareau, G., Aubourg, C., Dubois, M., Lacroix, B., Branellec, M., Callot, J.P., Vennemann, T., 2018. Syn-orogenic fluid flow in the Jaca basin (south Pyrenean fold and thrust belt) from fracture and vein analyses. Basin Research, $1-30$.

Cruset, D., 2019. Sequential fluid migration along a fold and thrust belt: SE Pyrenees from Late Cretaceous to Oligocene. PhD thesis, Universitat de Barcelona, Barcelona, Spain, p. 350.

Cruset, D., Cantarero, I., Travé, A., Vergés, J., John, C.M., 2016. Crestal graben fluid evolution during growth of the Puig-reig anticline (South Pyrenean fold and thrust belt). Journal of Geodynamics 101, 30-50.

Cruset, D., Cantarero, I., Vergés, J., John, C.M., Muñoz-López, D., Travé, A., 2018. Changes in fluid regime in syn-orogenic sediments during the growth of the south Pyrenean fold and thrust belt. Global and Planetary Change 171, 207-224.

Cruset, D., Cantarero, I., Vergés, J., Benedicto, A., John, C.M., Gerdes, A., Albert, R. \& Travé, A. 2019. Tectonically-induced oil migration in the south-eastern Pyrenean foreland basin. 34th International Meeting of Sedimentology (IAS), Rome.

Cruset, D., Cantarero, I., Benedicto, A., John, C.M., Vergés, J., Albert, R., Gerdes, A. \& Travé, A. 2020. From hydroplastic to brittle deformation: Controls on fluid flow in fold and thrust belts. Insights from the Lower Pedraforca thrust sheet (SE Pyrenees). Marine and Petroleum Geology, 120, 104517. 
Fillon, C. \& Beek, P.v.d. 2012. Post-orogenic evolution of the southern Pyrenees: constraints from inverse thermo-kinematic modelling of low-temperature thermochronology data. Basin Research, 23, 1-19.

Fitzgerald, P.G., Muñoz, J.A., Coney, P.J. \& Baldwin, S.L. 1999. Asymmetric exhumation across the Pyrenean Orogen; implications for the tectonic evolution of a collisional orogen. Earth and Planetary Science Letters, 173, 157-170.

García-Castellanos, D., Vergés, J., Gaspar-Escribano, J., Cloetingh, S., 2003. Interplay between tectonics, climate, and fluvial transport during the Cenozoic evolution of the Ebro Basin (NE Iberia). Journal of Geophysical Research 108, (B7), 2347.

Gerdes, A., Zeh, A., 2006. Combined U-Pb and Hf isotope LA-(MC-)ICP-MS analyses of detrital zircons: Comparison with SHRIMP and new constraints for the provenance and age of an Armorican metasediment in Central Germany. Earth and Planetary Science Letters 249, 47-61.

Gerdes, A., Zeh, A., 2009. Zircon formation versus zircon alteration - New insights from combined U-Pb and Lu-Hf in-situ La-ICP-MS analyses of Archean zircons from the Limpopo Belt. Chemical Geology 261, 230-243.

Gibson, M., Sinclair, H.D., Lynn, G.J. \& Stuart, F.M. 2007. Late- to post-orogenic exhumation of the Central Pyrenees revealed through combined thermochronological data and modelling. Basin Research, 19, 323-334.

Grool, A.R., Ford, M., Vergés, J., Huismans, R.S., Christophoul, F., Dielforder, A., 2018. Insights Into the Crustal-Scale Dynamics of a Doubly Vergent Orogen From a Quantitative Analysis of Its Forelands: A Case Study of the Eastern Pyrenees. Tectonics 37, 450-476.

Hansman, R.J., Albert, R., Gerdes, A., Ring, U., 2018. Absolute ages of multiple generations of brittle structures by U-Pb dating of calcite. Geology 46, 207-210. 
Horstwood, M.S.A., Košler, J., Gehrels, G., Jackson, S.E., McLean, N.M., Paton, C., Pearson, N.J., Sircombe, K., Sylvester, P., Vermeesch, P., Bowring, J.F., Condon, D.J. and Schoene, B. 2016. Community-Derived Standards for LA -ICP -MS U-(Th-)Pb Geochronology - Uncertainty Propagation, Age Interpretation and Data Reporting. Geostandards and Geoanalytical Research 40, 311-332.

Linnemann, U., Ovtcharova, M., Schaltegger, U., Gärtner, A., Hautmann, M., Geyer, G., Vickers-Rich, P., Rich, T., Plessen, B., Hofmann, M., Zieger, J., Krause, R., Kriesfeld, L., Smith, J., 2018. New high-resolution age data from the EdiacaranCambrian boundary indicate rapid, ecologically driven onset of the Cambrian explosion. Terra Nova 31, 49-58.

Ludwig, K.R. 2012. User's manual for Isoplot Version 3.75: A geochronological toolkit for Microsoft Excel. Berkeley Geochronology Center Special Publication, 5.

Meigs, A.J., Vergés, J., Burbank, D.W., 1996. Ten-million-year history of a thrust sheet. GSA Bulletin 108, 1608-1625.

Mottram, C., Parrish, R.R., Regis, D., Warren, C.J., Argles, T.W., Harris, N.B.W., Roberts, N.M.W., 2015. Using U-Th-Pb petrochronology to determine rates of ductile thrusting: Time windows into the Main Central Thrust, Sikkim Himalaya. Tectonics 34, 1355-1374.

Muñoz, J.A., 1992. Evolution of a continental collision belt: ECORS-Pyrenees crustal balanced section, in: McClay, K.R. (Ed.), Thrust Tectonics. Chapman \& Hall, London, pp. 235-246.

Muñoz, J.A., 2002. The Pyrenees, in: Gibbons, W., Moreno, T. (Eds.), The Geology of Spain. Geological Society, London, pp. 370-385.

Nardini, N., Muñoz-López, D., Cruset, D., Cantarero, I., Martín-Martín, J.D., Benedicto, A., Gómez-Rivas, E., John, C.M., Travé, A., 2019. From early 
contraction to post-folding fluid evolution in the frontal part of the Bóixols thrust sheet (southern Pyrenees) as revealed by the texture and geochemistry of calcite cements. Minerals 9, 117.

Parrish, R.R., Parrish, C.M., Lasalle, S., 2018. Vein calcite dating reveals Pyrenean orogen as cause of Paleogene deformation in southern England. Journal of the Geological Society 175, 425-442.

Pérez-Rivarés, F.J., Arenas, C., Pardo, G. \& Garcés, M. 2018. Temporal aspects of genetic stratigraphic units in continental sedimentary basins: Examples from the Ebro basin, Spain. Earth-Science Reviews, 178, 136-153.

Puigdefàbregas, C. \& Souquet, P. 1986. Tecto-sedimentary cycles and deposition sequences of the Mesozoic and Tertiary from the Pyrenees. Tectonophysics, 129, 173-203.

Puigdefàbregas, C., Muñoz, J.A. \& Marzo, M. 1986. Thrust Belt Development in the Eastern Pyrenees and Related Depositional Sequences in the Southern Foreland Basin. In: Allen, P.A. \& Homewood, P. (eds) Foreland Basins. Blackwell Publishing Ltd., Oxford, UK. , 8, 229-246.

Rahl, J.M., Haines, S.H., Pluijm, B.A.v.d., 2011. Links between orogenic wedge deformation and erosional exhumation: Evidence from illite age analysis of fault rock and detrital thermochronology of syn-tectonic conglomerates in the Spanish Pyrenees. Earth and Planetary Science Letters 307, 180-190.

Ring, U., Gerdes, A., 2016. Kinematics of the Alpenrhein-Bodensee graben system in the Central Alps: Oligocene/Miocene transtension due to formation of the Western Alps arc. Tectonics 35, 1367-1391. 
Roberts, N.M.W., Rasbury, E.T., Parrish, R.R., Smith, C.J., Horstwood, M.S.A., Condon, D.J., 2017. A calcite reference material for LA-ICP-MS U-Pb geochronology. Geochemistry, Geophysics, Geosystems 18, 2807-2814.

Roure, F., Choukroune, P., Berastegui, J., Muñoz, J.A., Villien, A., Matheron, P., Bareyt, M., Seguret, M., Camara, P., Deramond, J., 1989. Ecors deep seismic data and balanced cross sections: Geometric constraints on the evolution of the Pyrenees. Tectonics 8, 41-50.

Roure, F., Swennen, R., Schneider, F., Faure, J.L., Ferket, H., Guilhaumou, N., Osadetz, K., Robion, P., Vandeginste, V., 2005. Incidence and Importance of Tectonics and Natural Fluid Migration on Reservoir Evolution in Foreland Fold-andThrust Belts. Oil \& Gas Science and Technology 60, 67-106.

Rushlow, C.R., Barnes, J.B., Ehlers, T.A., Vergés, J., 2013. Exhumation of the southern Pyrenean fold-thrust-belt (Spain from orogenic growth to decay. Tectonics 32, 843-860.

Sans, M., Muñoz, J.A., Vergés, J., 1996. Triangle zone and thrust wedge geometries related to evaporitic horizons (Southern Pyrenees). Canadian Petroleum Geology Bulletin 4, 375-384.

Saura, E., Oró, L.A.i., Teixell, A. \& Vergés, J. 2015. Rising and falling diapirs, shifting depocenters, and flap overturning in the Cretaceous Sopeira and Sant Gervàs subbasins (Ribagorça Basin, southern Pyrenees). Tectonics, 35.

Séguret, M., 1972. Étude tectonique des nappes et séries décollées de la partie centrale du vesant sud des Pyrénées. Pub. USTELA, sér, Geol. Struct. n.2, Montpellier.

Tavani, S., Granado, P., Arbués, P., Corradetti, A. \& Muñoz, J.A. 2017. Syn-thrusting, near-surface flexura-slipping and stress deflection along folded sedimentary 

layers of the Sant Corneli-Bóixols anticline (Pyrenees, Spain). Solid Earth, 8, 405-419.

Teixell, A., Labaume, P., Ayarza, P., Espurt, N., Blanquat, M.d.S., Lagabrielle, Y., 2018. Crustal structure and evolution of the Pyrenean-Cantabrian belt: A review and new interpretations from recent concepts and data. Tectonophysics 724-725, 146-170.

Travé, A., Labaume, P., Calvet, F. \& Soler, A. 1997. Sediment dewatering and pore fluid migration along thrust faults in a foreland basin inferred from isotopic and elemental geochemical analyses (Eocene southern Pyrenees, Spain). Tectonophysics, 282, 375-398.

Travé, A., Labaume, P., Calvet, F., Soler, A., Tritlla, J., Bautier, M., Potdevin, J.L., Séguret, M., Raynaud, S., Briqueu, L., 1998. Fluid migration during Eocene thrust emplacement in the south Pyrenean foreland basin (Spain): an integrated structural, mineralogical and geochemical approach, in: Mascle, A., Puigdefàbregas, C., LuterBacher, H.P., Fernàndez, M. (Eds.), Cenozoic Foreland Basins of Western Europe. Geological Society, Special Publications, pp. 163188.

Travé, A., Labaume, P., Vergés, J., 2007. Fluid systems in Foreland Fold and thrust belts: an overview from the Southern Pyrenees, in: Lacombe, O., Lavé, J., Roure, F., Vergés, J. (Eds.), Thrust Belts and Foreland Basins: From Fold Kinematics to Hydrocarbon Systems. Springer, pp. 93-115.

Vaks, A., Woodhead, J., Bar-Matthews, M., Ayalon, A., Cliff, R.A., Zilberman, T., Matthews, A. \& Frumkin, A. 2013. Pliocene-Pleistocene climate of the northern margin of Saharan-Arabian Desert recorded in speleothems from the Negev Desert, Israel. Earth and Planetary Science Letters, 358, 88-100. 
559 Vergés, J., 1993. Estudi geològic del vessant sud del Pirineu oriental i central. Evolució cinemàtica en 3D. PhD thesis, Universitat de Barcelona, Barcelona, Spain, p. 203.

562 Vergés, J., Fernàndez, M., Martínez, A., 2002. The Pyrenean orogen: pre-, syn-, and post-collisional evolution, in: Rosenbaum, G., Lister, G. (Eds.), Reconstruction of the evolution of the Alpine-Himalayan Orogen. Journal of the Virtual Explorer, pp. 55-74.

Vergés, J., Martínez, A., Muñoz, J.A., 1992. South Pyrenean fold and thrust belt: The role of foreland evaporitic levels in thrust geometry, in: McClay, K. (Ed.), Thrust Tectonics. London, Chapman \& Hall, pp. 255-264.

Zhang, P.Z., Shen, Z., Wang, M., Gan, W., Bürgmann, R., Molnar, P., Wang, Q., Wu, J., Sun, J., Hanrong, S., Xinzhao, Y., Niu, Z., 2004. Continuous deformation of the Tibetan Plateau from global positioning system data. Geology 32, 809-812. 


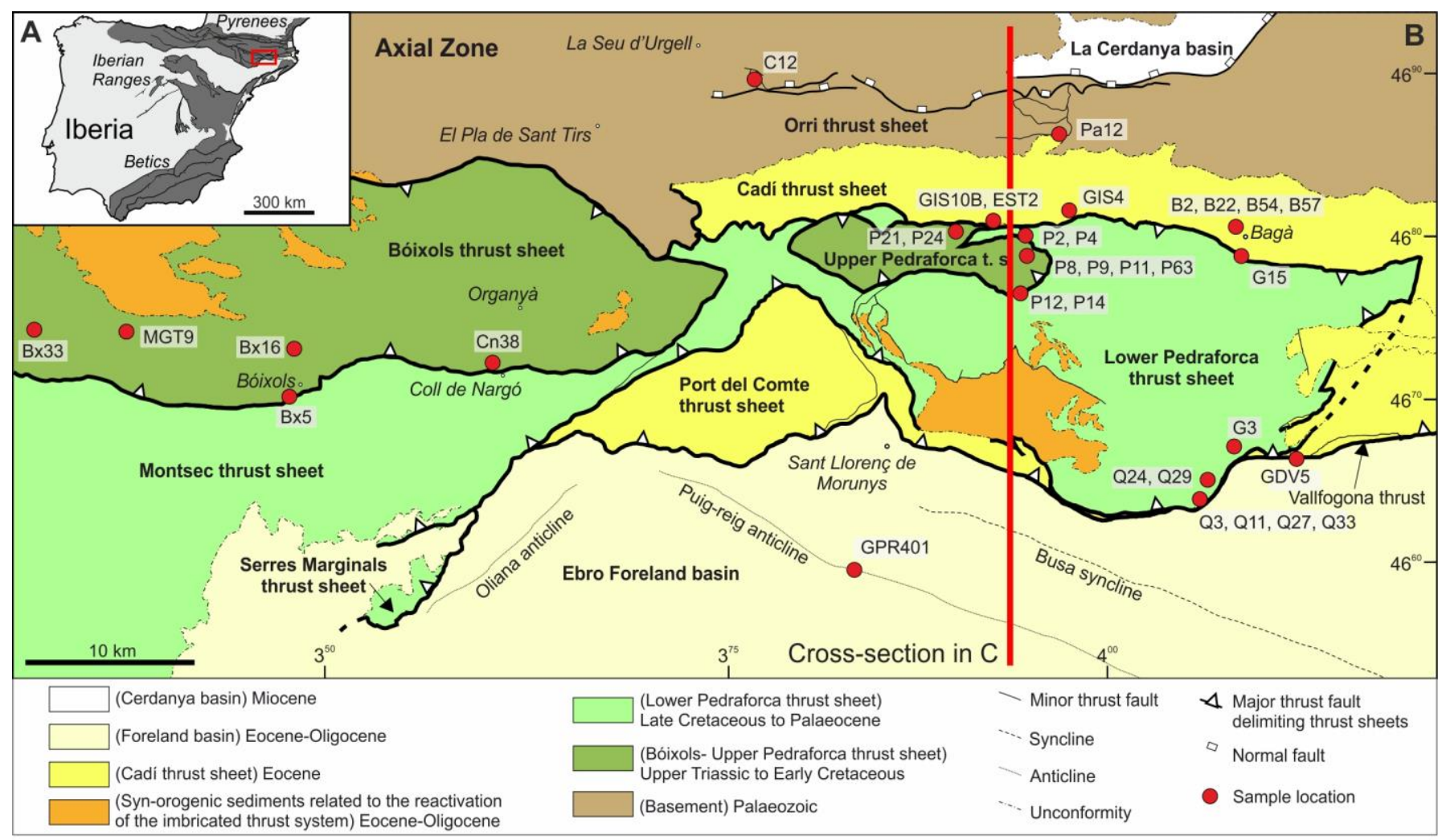

C

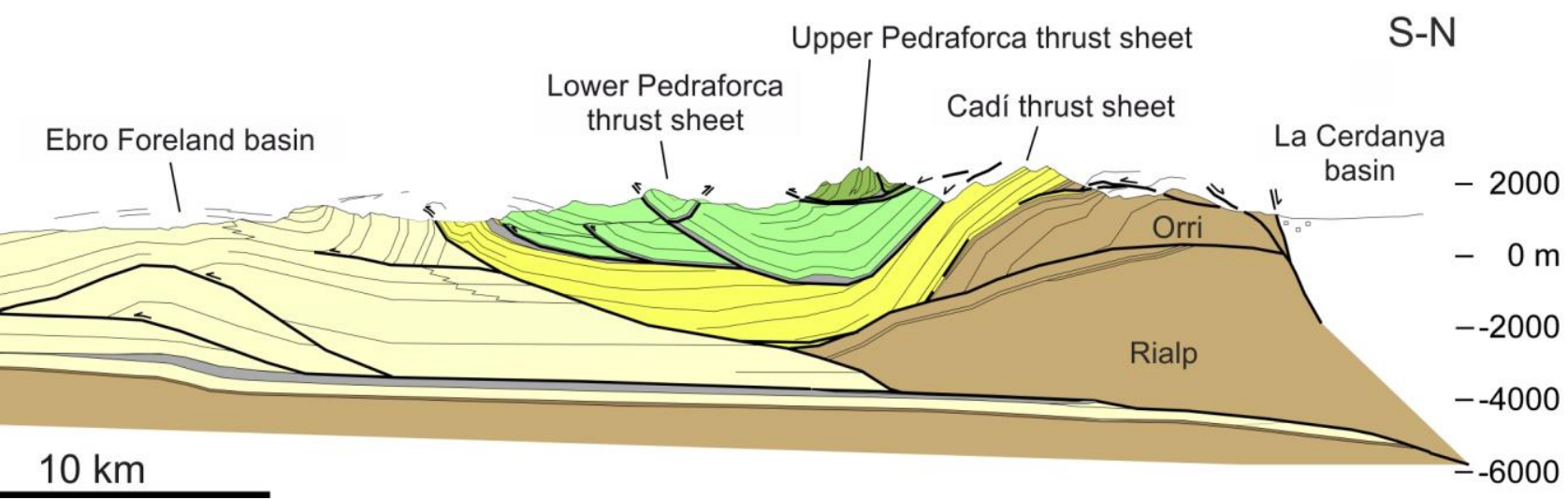

573 Fig. 1. A) Simplified map of Iberia reporting the location of the Pyrenees and the studied area.

574 B) Structural sketch of the studied area with the location of the studied structures and suitable

575 samples for dating. The red line shows the location of the cross-section in C. For locations of

576 samples where U-Pb dating failed see Table S1. C) Geological cross-section of the SE Pyrenees

577 from Vergés (1993). 

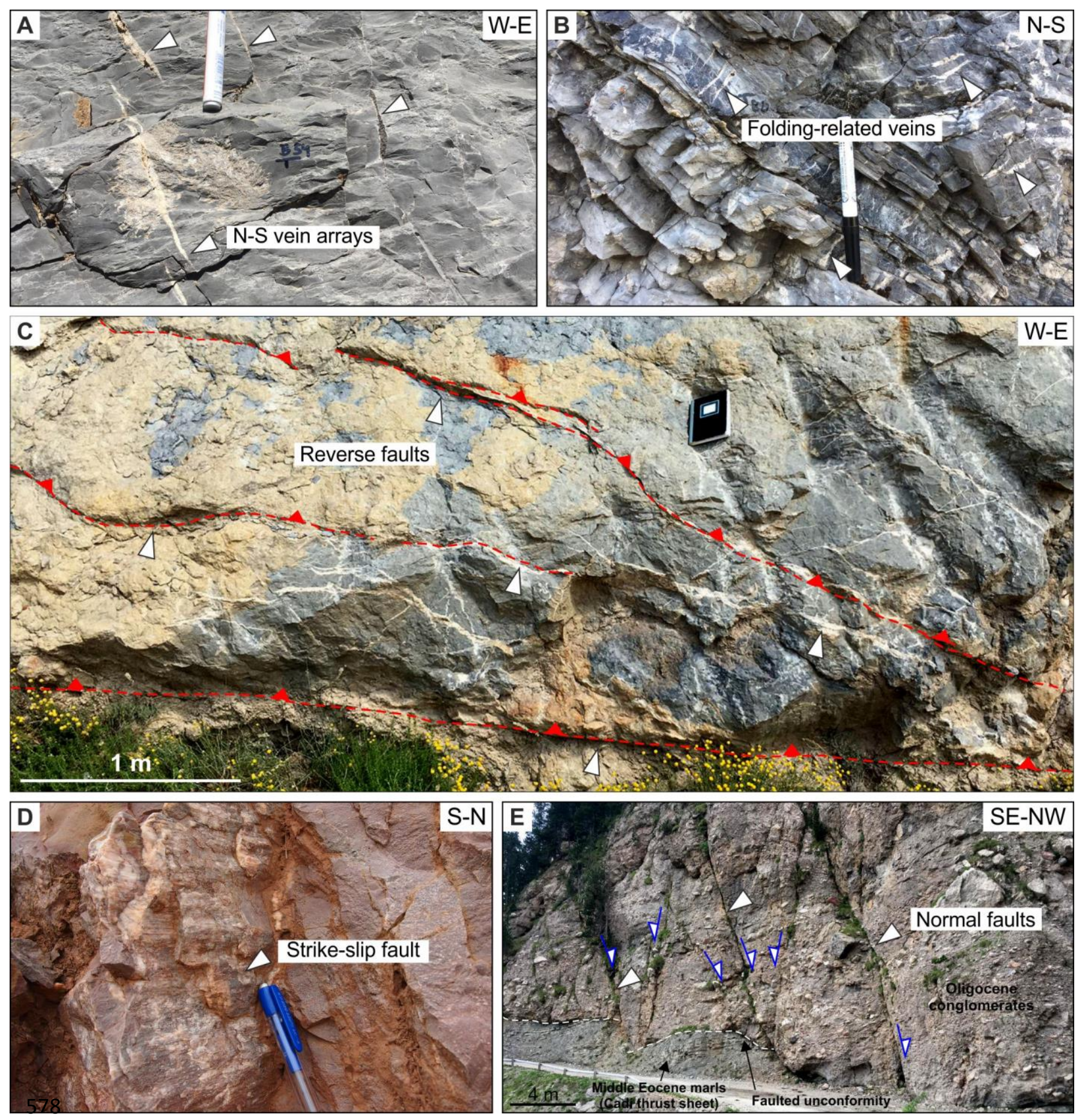

579 Fig. 2. Representative images of the five fracture sets observed in the study area. A) En-échelon

580 vein arrays, Cadí thrust sheet; B) Folding related veins, Cadí thrust sheet; C) Reverse faults,

581 Lower Pedraforca thrust sheet; D) Strike-slip faults, Bóixols-Upper Pedraforca thrust sheet; E)

582 Normal faults, Lower Pedraforca thrust sheet. 

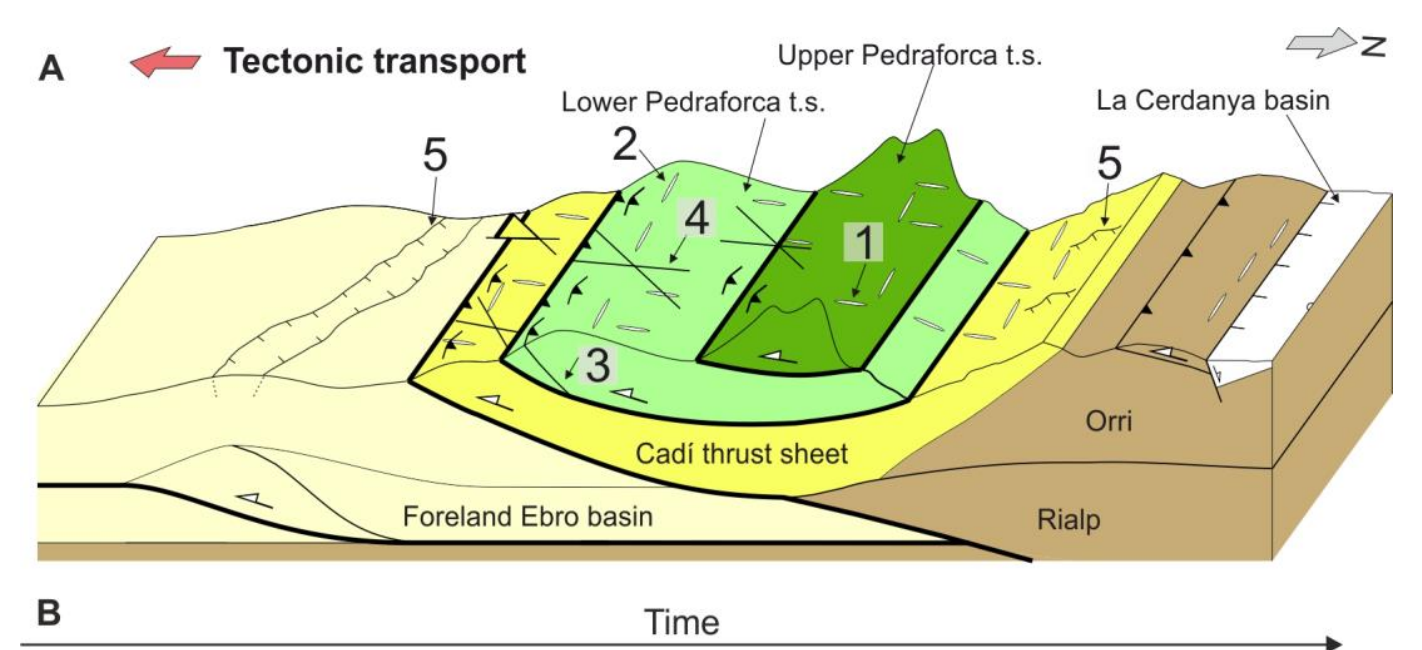

583

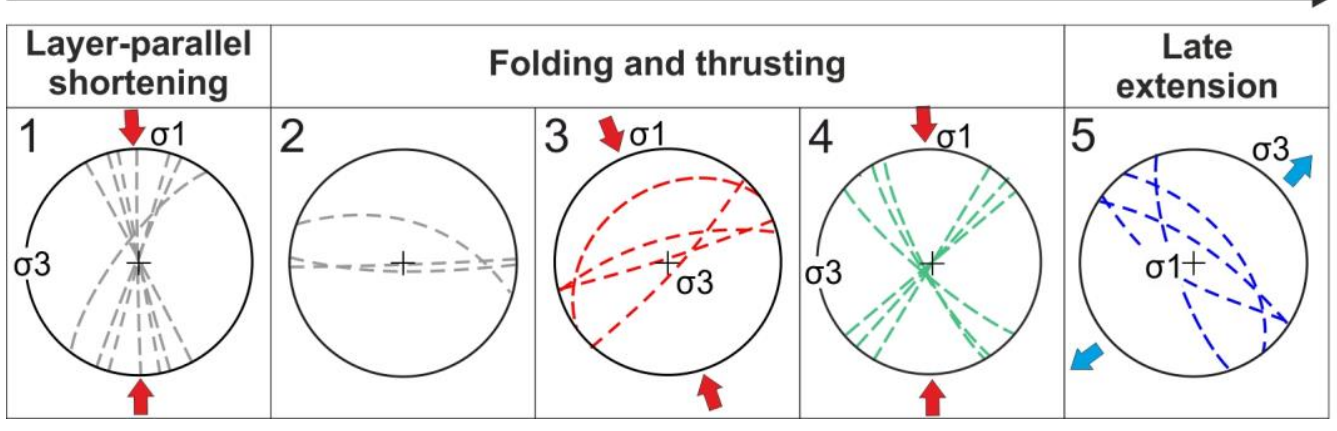

584 Fig. 3. A) Sketch representing the five fracture sets identified in this study: 1) En-échelon vein

585 arrays; 2) Folding related veins; 3) Reverse faults; 4) Strike-slip faults; 5) Normal faults. For

586 complementary details see Cruset et al. (2016, 2018 and 2020), Cruset (2019) and Nardini et al.

587 (2019). B) Stereographic projections of the mean orientation of fractures 1 to 5 calculated from

588 fracture data presented in Fig. S1. 

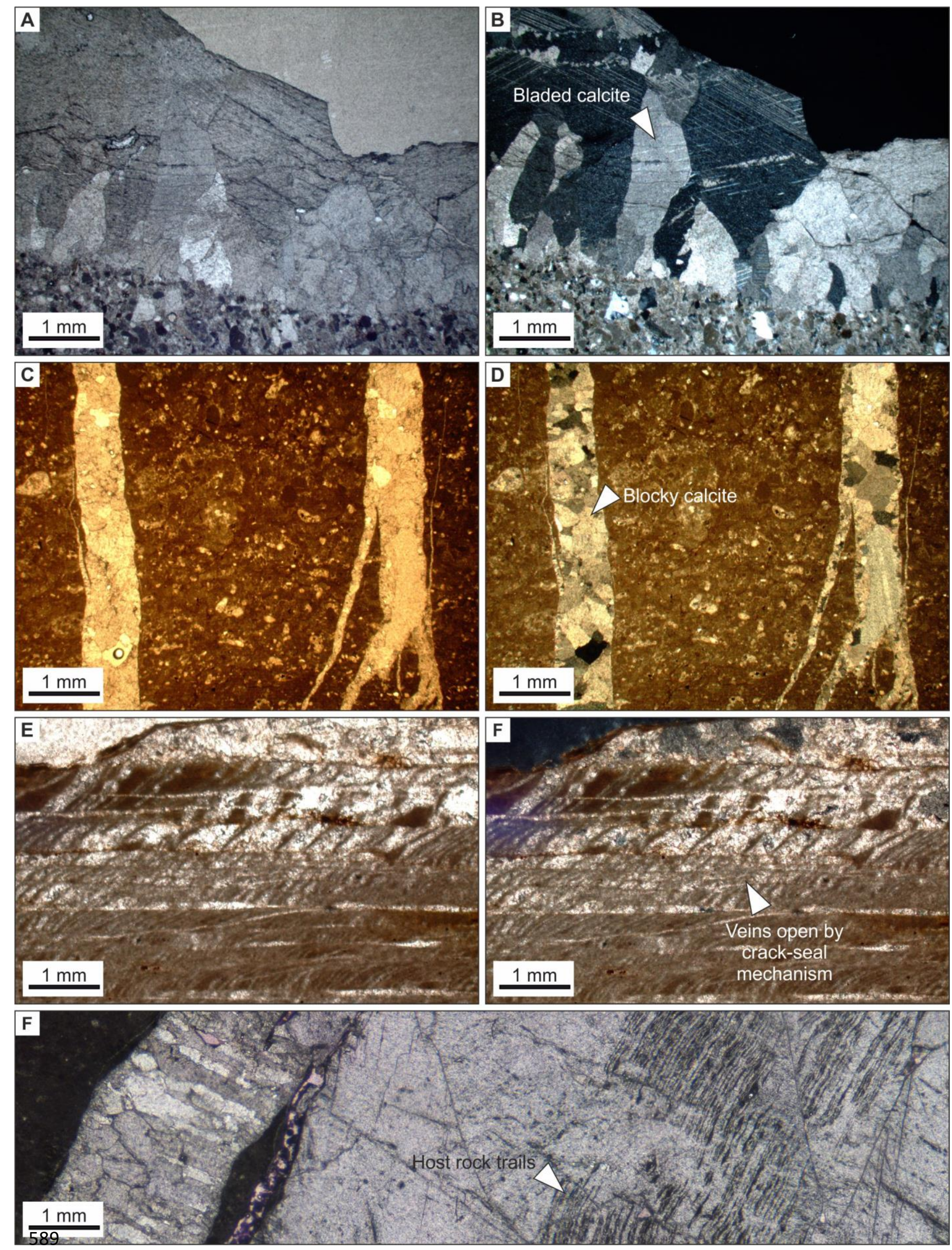
590 Fig. 4. Optical microscope images (parallel and crossed Nicols) of the main features of the

591 Bladed and blocky calcite crystals. A-B) Bladed calcite. C-D) Blocky crystals within N-S vein

592 arrays. E-F) Blocky calcite crystals precipitated in rhomb-shaped veinlets formed by crack-seal

593 mechanism in a strike-slip fault. G) N-S vein formed by crack-seal mechanism and filled with

594 blocky crystals. Note how host-rock trials arranged parallel to fracture walls and perpendicular

595 to the opening direction are included within the calcite cement. 

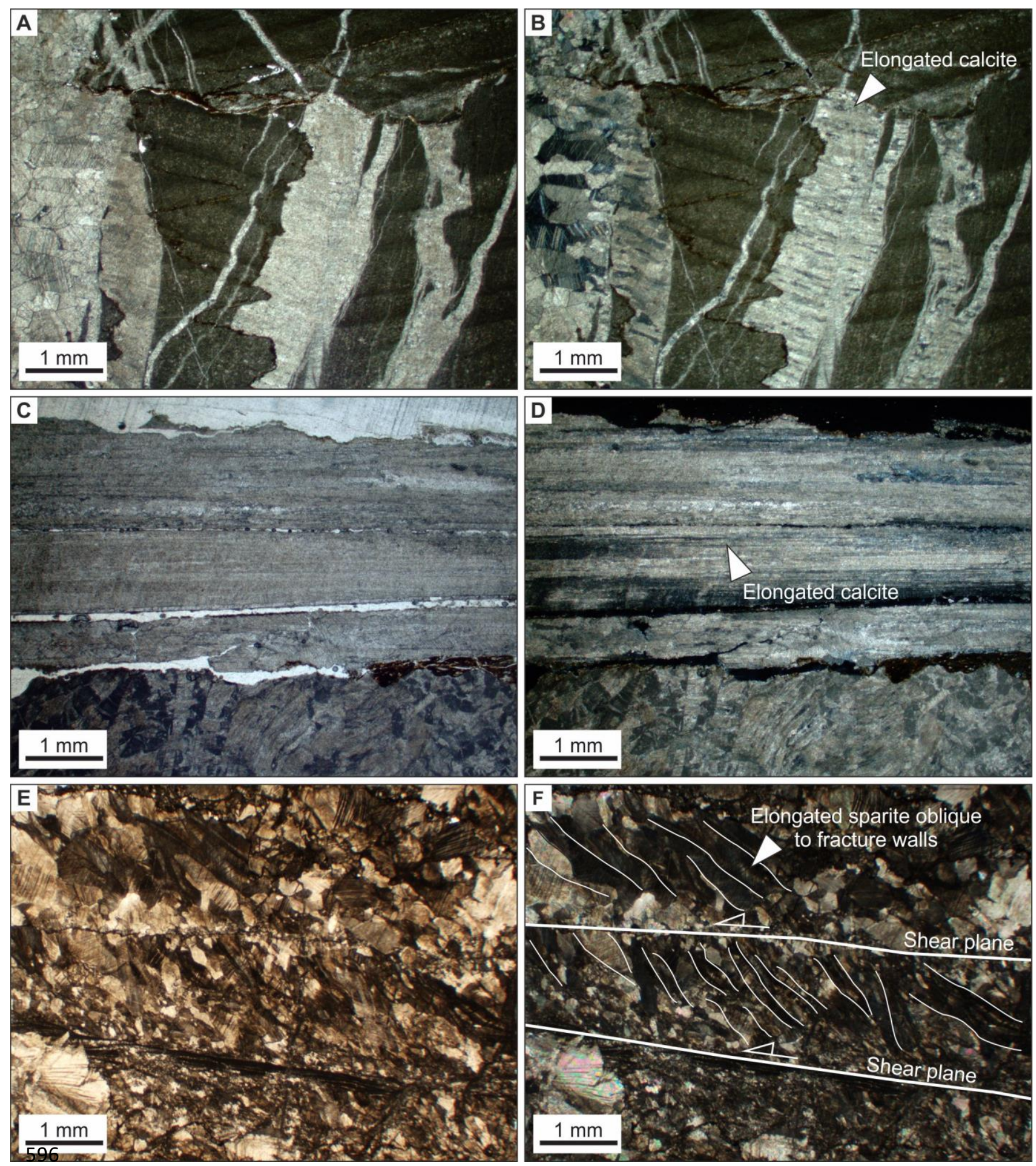

597 Fig. 5 Optical microscope images (parallel and crossed Nicols) of the main features of the

598 elongated crystals. A-B) Elongated crystals perpendicular to the walls of a N-S vein. B-C)

599 Elongated crystals parallel to the walls of a reverse fault. C-D) Elongated crystals oblique to 
600 fracture walls of a reverse faults. Note how the disposition of the crystals indicate the sense of 601 shear. 


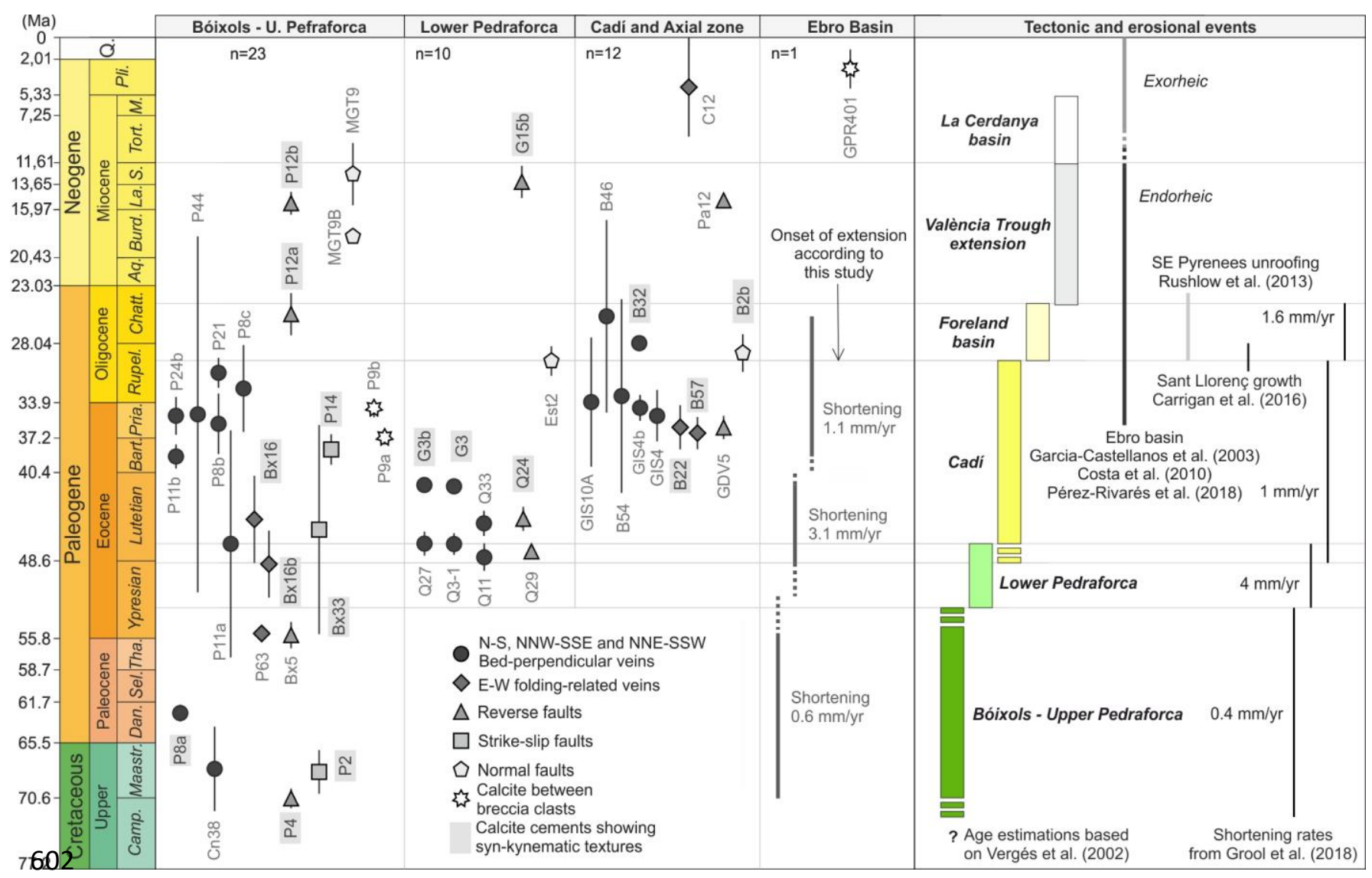

603 Fig. $6 \mathrm{U}-\mathrm{Pb}$ dates from SE Pyrenean fold and thrust belt and calculated shortening rates. Colour

604 bars on the right indicate previous age estimations of the Pyrenean compression and NE Iberian

605 extension based on Vergés et al. (2002). Ages for the Cadí unit and for the tectonic activity of

606 the foreland Ebro basin are modified according to Rushlow et al. (2013), Meigs et al. (1996) and

607 Carrigan et al. (2016). The timing of the development of the endorheic to exorheic foreland

608 Ebro basin is based on Garcia-Castellanos et al. (2003) and Costa et al. (2010). 


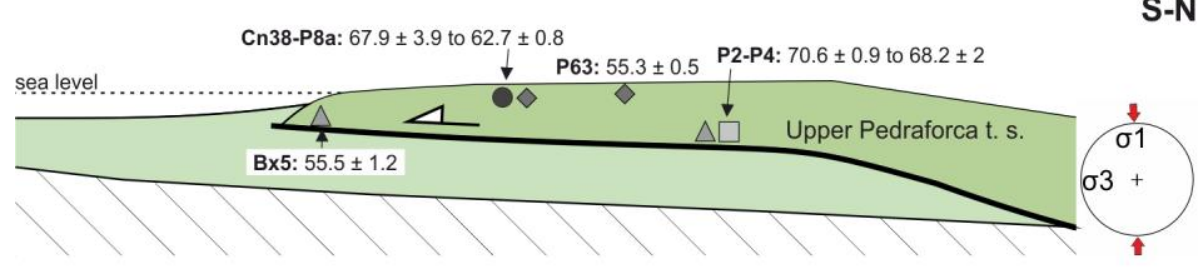

\section{Early-middle Eocene}

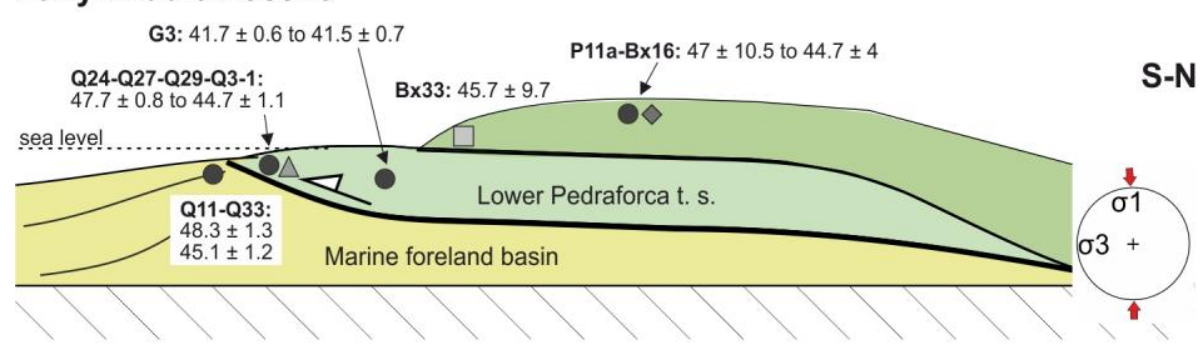

\section{Late Eocene-Late Oligocene}

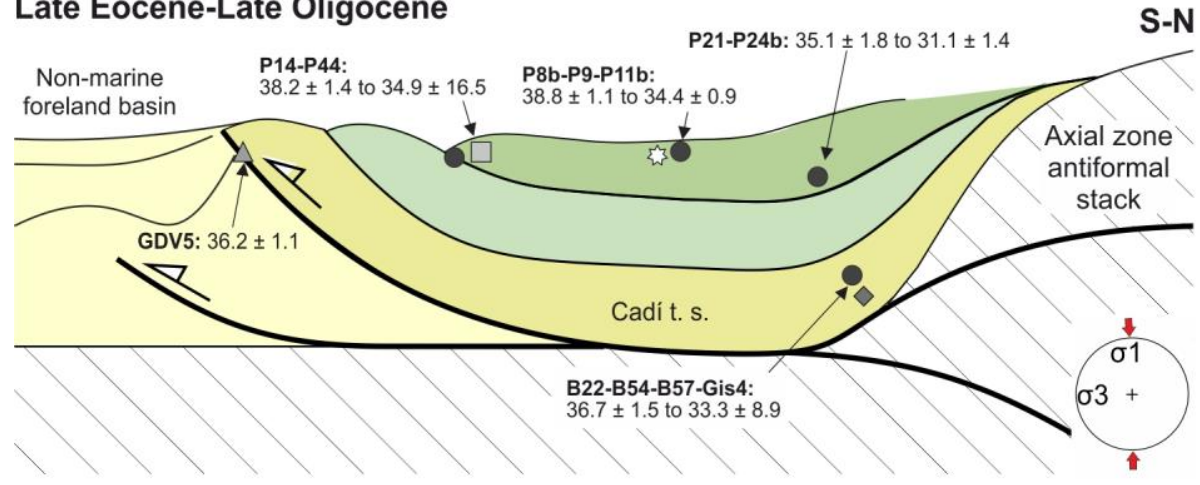

\section{Late Oligocene-Miocene}



610 Fig. 7. Simplified sketch of the southern Pyrenees based on U-Pb ages showing the sequence of

611 deformation and its propagation to the foreland. Symbols represent the type of fracture as shown in Fig. 6. Error of ages are reported in Fig. 6. 


\begin{tabular}{ccccccc}
\hline Sample & Cement Type & $\mathrm{n}$ & $\Delta_{47}$ & $\mathrm{~T} \stackrel{\circ}{\mathrm{C}}$ & $\begin{array}{c}\text { Measured U-Pb } \\
\text { age? }\end{array}$ & Reference \\
\hline
\end{tabular}

Bóixols-Upper Pedraforca thrust sheet

$\begin{array}{ccccccc}\text { CN33 } & \text { Cc1 } & 2 & 0.54 \pm 0.006 & 88.4 \pm 3.8 & \text { No } & \begin{array}{c}\text { Nardini et al. } \\ (2019) \\ \text { Nardini et al. } \\ (2019) \\ \text { CN38 }\end{array} \\ \text { Cc2 } & 1 & 0.646 & 40.7 \pm 16.1 & \text { Yes } & \begin{array}{c}\text { Nardini et al. } \\ (2019)\end{array} \\ \text { CN20 } & \text { Cc3 } & 2 & 0.55 \pm 0.007 & 85.3 \pm 4 & \text { No } & \begin{array}{c}\text { Nardini et al. } \\ (2019) \\ \text { CN15 }\end{array} \\ \text { Cc4 } & 2 & 0.54 \pm 0.001 & 87.6 \pm 0.6 & \text { No } & \text { Cruset (2019) } \\ \text { P24 } & \text { Dc1 } & 4 & 0.46 \pm 0.014 & 149.4 \pm 12.5 & \text { No } & \text { Cruset (2019) } \\ \text { P32/P75 } & \text { Dc2 } & 4 & 0.49 \pm 0.008 & 124.7 \pm 6.2 & \text { No } & \text { Cruset (2019) } \\ \text { P4 } & \text { Cc4 } & 1 & 0.556 & 81 \pm 21.7 & \text { Yes } & \text { Cruset (2019) } \\ \text { P2 } & \text { Cc5 } & 3 & 0.56 \pm 0.022 & 79.7 \pm 12 & \text { Yes } & \text { Cruset (2019) } \\ \text { P7/P9 } & \text { Cc10 } & 1 & 0.675 & 30.3 \pm 13.6 & \text { Yes } & \text { Cruset (2019) } \\ \text { P14/P15 } & \text { Cc7 } & 3 & 0.52 \pm 0.007 & 100.78 \pm 4.2 & \text { Yes } & \text { Cruset (2019) } \\ \text { P6/P8 } & \text { Cc8 } & 4 & 0.52 \pm 0.008 & 101.4 \pm 5 & \text { Yes } & \text { Cruset (2019) } \\ \text { P44 } & \text { Cc14 } & 4 & 0.58 \pm 0.009 & 67.27 \pm 4.8 & \text { Yes } & \end{array}$

Lower Pedraforca thrust sheet

$\begin{array}{ccccccc}\text { Q2/Q27/Q3-1 } & \text { Cc3 } & 4 & 0.58 \pm 0.011 & 69.08 \pm 5.34 & \text { Yes } & \begin{array}{c}\text { Cruset et al. } \\ (2020) \\ \text { Cruset et al. } \\ \text { Q24 }\end{array} \text { Cc6 }^{2020)}\end{array}$

\section{Cadí thrust sheet}

$\begin{array}{ccccccc}\text { GDV30/GDV26 } & \text { Cc2 } & 3 & 0.46 \pm 0.002 & 154 \pm 2 & \text { No } & \begin{array}{c}\text { Cruset et al. } \\ (2018) \\ \text { Cruset et al. } \\ \text { (2018) }\end{array} \\ \text { B34/B2 } & \text { Cc5 } & 3 & 0.53 \pm 0.023 & 105 \pm 14 & \text { No } & \begin{array}{c}\text { Cruset et al. } \\ (2019)\end{array} \\ \text { B22 } & \text { Cc2 } & 4 & 0,50 \pm 0.028 & 113 \pm 10 & \text { No } & \begin{array}{c}\text { Cruset et al. } \\ (2019)\end{array}\end{array}$

\section{Ebro foreland basin}

\begin{tabular}{|c|c|c|c|c|c|c|}
\hline $309 B$ & Cc1 & 3 & $0.548 \pm 0.009$ & $92 \pm 5$ & No & $\begin{array}{l}\text { Cruset et al } \\
\quad(2016)\end{array}$ \\
\hline 317 & $\mathrm{Cc} 1$ & 3 & $0.49 \pm 0.010$ & $129 \pm 8$ & No & $\begin{array}{c}\text { Cruset et al } \\
(2016)\end{array}$ \\
\hline $311 \mathrm{D}$ & Cc2 & 3 & $0.551 \pm 0.004$ & $90 \pm 3$ & No & $\begin{array}{l}\text { Cruset et al } \\
\quad(2016)\end{array}$ \\
\hline $311 \mathrm{~A}$ & $\mathrm{Cc} 2$ & 3 & $0.574 \pm 0.010$ & $77 \pm 5$ & No & $\begin{array}{l}\text { Cruset et al } \\
\quad(2016)\end{array}$ \\
\hline
\end{tabular}

613

614 Table 1. Available $\Delta_{47}$ and clumped temperatures measured in the dated calcites and dolomites

615 in the SE Pyrenees. Data from Cruset et al. (2016; 2018; 2019; 2020), Cruset (2019) and

616 Nardini et al. (2019). 